\title{
Residents' practice and perceptions during the COVID-19 pandemic
}

\author{
Miao Fang ${ }^{1}$, Shunju Xiang ${ }^{1}$, and Yang $\mathrm{Si}^{1}$ \\ ${ }^{1}$ Affiliation not available
}

November 18, 2020

\begin{abstract}
Rationale, aims and objectives: This study aimed to determine the residents' perspectives on clinical practice during the pandemic of coronavirus disease 2019 (COVID-19). Methods: A cross-sectional survey was carried out online among medical residents in our hospital. The survey covered basic information, condition of clinical practice, and perspectives related to the COVID-19. Results: total 174 (26.8\%) residents responded and completed the survey. Nearly half of the residents (51.7\%) expressed willingness of going to the frontline to fight against the virus and $62.3 \%$ of the residents showed good morale. Online courses were delivered to $87.9 \%$ of the residents with satisfaction at $89.7 \%$. Approximate one third of the residents concerned the impact of the epidemic on graduation (34.0\%) and taking up an occupation (32.8\%). Majorities (79.3\%) determined to be a doctor after the pandemic. Notablely $40.2 \%$ of the residents thought they were underpaid. $21.8 \%$ of the residents reported to be unfairly treated in clinical practice. Overall no statistical differences were revealed between internal medicine and surgery residents, and between those married and singles, regarding the perceptions related to the COVID-19. Conclusion: Administrators should take cognizance of perspective of the residents and formulate corresponding strategies to reassure trainees' safety and continuous training, address the residents' concerns and get prepared for the second wave of COVID-19.
\end{abstract}

\section{Hosted file}

paper.pdf available at https://authorea.com/users/376746/articles/493644-residents-practiceand-perceptions-during-the-covid-19-pandemic

\section{Hosted file}

Tables .pdf available at https://authorea.com/users/376746/articles/493644-residents-practiceand-perceptions-during-the-covid-19-pandemic 